\title{
Guest editorial: the role of corporate entrepreneurship in the current organizational and economic landscape
}

\author{
Jeff Hornsby • Iñaki Peña-Legazkue • \\ Maribel Guerrero
}

Published online: 5 May 2013

(C) Springer Science+Business Media New York 2013

\section{Introduction}

Research on corporate entrepreneurship (CE) has grown rapidly over the past decades. Past studies from several complementary fields such as management, strategy, finance, entrepreneurship and marketing, have contributed to a better understanding of this complex and dynamic of entrepreneurship within established organizations. Particularly, previous special issues published in well-know journals evidenced a clear evolution from building to testing theories, methods from qualitative to more sophisticated quantitative analysis and findings in different contexts (see Table 1 in Appendix). To date, there are still unexplored issues. Since 90's, Guth and Ginsberg (1990) identified opportunities and challenges to extend the study of corporate entrepreneurship in a global context as how the changes in the international environment influence strategic management. Ten years later, Zahra et al. (1999) argued the necessity to developing better theory building in CE research. Twenty years later, Phan et al. (2009) recognized the limits of applicability of certain theories developed in CE in different contexts. Yet, little is known about the CE activity across different regions (Antoncic and Hisrich 2001; Dess et al. 2003; Gómez-Haro et al. 2011; Yang and Li 2011; Zahra and Covin 1995).

In recent years, the world economic crisis has destroyed a vast number of companies and millions of jobs. For some established organizations, it represents strong challenges in their survived rate and growth patterns. For other organizations, it could represents a fertile environment to identify entrepreneurial opportunities (Alpkan et al. 2010; McMullen and Shepherd 2006; Mousa and Wales 2012; Renko et al. 2012). Following this point of view, this special issue focuses on analyzing the role of CE in

\footnotetext{
J. Hornsby

Henry Block/Missouri Endowed Chair of Entrepreneurship and Innovation, Regnier Institute for

Entrepreneurship and Innovation, University of Missouri Kansas City, Manhattan, KS, USA

I. Peña-Legazkue $\cdot$ M. Guerrero $(\bowtie)$

Entrepreneurship Department, Orkestra-Basque Institute of Competitiveness and Deusto Business School, San Sebastian, Spain

e-mail: maribel.guerrero@orkestra.deusto.es
} 
the current organizational and economical reality faced by established organizations. In this sense, six articles included in this special issue contribute to:

(a) Clarify the theoretical boundaries of CE research: strategic entrepreneurship and corporate venturing. But also, clarify the requirements of international CE.

(b) Explore individual's behaviours (Bottom-up and Top-down approach), organizational process (dispersed) and work contexts (informal and formal) behind strategic entrepreneurship.

(c) Explore individual (specific human capital), organizational (networks, resources and capabilities) and external factors (informal and formal) behind corporate venturing

We first describe the main contributions of the six papers and later we include some directions for further research.

\section{Contributions of this special issue}

Given the nature and complexity of $\mathrm{CE}$, this special issue contains six papers authored by scholars from five countries (i.e.., Belgium, The Netherlands, Spain, UK and USA). Their research covers theoretical and empirical papers about the role of $\mathrm{CE}$ in the current organizational and economic landscape. Theoretical papers clarify the general domain of CE manifested in companies either through strategic entrepreneurship and corporate venturing; and the main requirements of international CE. Empirical papers use a large range of research methods, from qualitative to quantitative analysis, exploring individual's behaviours, organizational process, work contexts and external factors of $\mathrm{CE}$ in advanced economies such as Asia, Europe and North America (see Table 2 in Appendix). Based on that, this special issue helps to:

Clarify the theoretical boundaries of CE research: strategic entrepreneurship and corporate venturing

Hornsby, Bloodgood, Hayton, and Kuratko suggest that international CE increasingly requires broader internal and external networks and legitimacy seeking in areas where the corporation and the entrepreneur are not well known. In this article, the important factors that influence the degree of legitimacy granted to corporate entrepreneurs are discussed. Three primary levels of legitimacy are suggested: pragmatic legitimacy, normative legitimacy, and structural legitimacy. A model is proposed that suggests that organizations move through these levels of legitimacy resulting in differing brokering behaviors for network building. Implications for future research are provided.

Kuratko and Audretsch's paper outlines and explains the various domains that currently exist in the research arena of CE. Authors describe the evolution of CE research over the last four decades: (i) in the 70's, CE focused on venture teams and how entrepreneurship inside existing organizations could be developed; (ii) in the 80 's, CE as embodying entrepreneurial behavior requiring organizational sanctions and resource commitments for the purpose of developing different types of value- 
creating innovations; (iii) in the 90's, CE as re-energizing and enhancing the firm's ability to develop new venture and strategic renewal; (iv) in 00's, CE as a set of entrepreneurial actions based on innovativeness, risk-taking, and proactiveness; and (v) in the 21 st century, $\mathrm{CE}$ as the foundation for profitable growth. The current domain defines $\mathrm{CE}$ as a manifestation of corporate venturing or strategic entrepreneurship within organizations. The authors concluded that a sharper focus on the CE process may be a most important step for scholars interested in moving the field forward.

Explore individual's behaviours and organizational process/work contexts behind strategic entrepreneurship

Rigtering and Weitzel's paper proposes a novel two-step theoretical model to understand the effect of formal (horizontal and vertical participation, resources available, formalization) and informal (trust in manager) work context on employees' behaviours (innovativeness, personal initiative and risk taking) such as the antecedent of intrapreneurship (active involvement in strategic projects). The authors focused on intrapreneurial activities initiated by intrapreneurs as employees that develop ideas and take hands on responsibility for the development of innovative new projects (bottom-up approach). Using a structural equation model, they tested the model on a sample of 176 employees from six Dutch companies. The evidence suggests that intrapreneurship is not affected directly by the work context but indirectly by the employees' behaviours. This study is the starting point of future investigations for exploring the complexity (formal and informal) work context and for predicting how intrapreneurship is stimulated within organizations.

Belousova and Gailly's investigation contributes with an analysis about the simultaneous behaviours and contributions of managers during the development of CE activities, as well as, the variations over time. The authors understand CE as the creation of new business ventures, products, services or technologies within establish firms. They offer an integrative theoretical framework for the CE process that would account for dynamic contributions of multiple actors through their activities and behaviors. Adopting this framework, during 2 years, the authors collected data regarding the process of three entrepreneurial initiatives (business units involved in the development of new products, new technologies or both) within a large European company. Their results bring an interesting perspective regarding individual behaviours and organizational process.

Explaining individual, organizational and external factors behind corporate venturing

Urbano and Turró's paper identifies which internal and external factors conditioned CE. In this paper, CE is analyzed as the intention to start new ventures by employees for their employer as part of their normal work. Authors proposed a novel theoretical framework that combines: Resource-Based View (for internal factors) and Institutional Economics (for external or environmental factors) perspectives. In particular, internal factors are knowledge, personal networks and 
being able to identify business opportunities, while, external factors are having fear of failure, media impact and the number of procedures to create a company. The proposed model is tested using data from nine European advanced economies (Greece, Spain, Italy, Ireland, the Netherlands, France, the United Kingdom, Denmark and Finland) that participate in the Global Entrepreneurship Monitor (GEM) project. Their results reinforce the importance of internal factors on corporate venturing but do not find support to the effect of external factors.

Guerrero and Peña's paper examines the influence of specific human capital (intrapreneurial experience) on corporate (the creation of new firms from existing organizations). The authors argue that organizations with entrepreneurial mind-sets build strong human architectures (i.e., management support, work discretion, reward system, time availability and organizational boundaries) that provide fertile environments inside organizations in order to achieve their organizational objectives (i.e., innovation, renewal or corporate venturing) and indirectly generates a valuable experience in the employees to lead intrapreneurial activities. This specific human capital is an intrapreneurial experience that complements other prior employees' experiences/knowledge (i.e., managerial, entrepreneurial, informal investor, labor experience). This specific human capital could also explain the differences among intrapreneurs and independent entrepreneurs. Using a sample of fulltime employees from advanced Asian, European and North American countries that participated in the 2011 Global Entrepreneurship Monitor (GEM) survey, the effect of intrapreneurial experience on the number of new ventures was analyzed. The results evidenced the positive effect of intrapreneurial experience on the creation of corporate venturing.

\section{Directions for future research}

The current economic recession brings interesting research opportunities to explore the direct, indirect or moderating effect of macroeconomic conditions on CE. At country level, would be interesting to analyze the level of entrepreneurship vs. corporate venturing in pre and post crisis periods. At organizational level, it would be interesting to examine the strategies, process and work context characteristics within organizations with entrepreneurial mind-set during this period. At individual level, it would be interesting to analyze the individual's behaviors and level of unemployed associated to organizations with entrepreneurial orientation and if the unemployment individual has become in an independent entrepreneur. We hope the papers in this special issue will inspire more research.

Acknowledgments A previous version of papers was presented at the 2012 Workshop on CE that took place at Deusto Business School on July $19 \& 20$ in Donostia-San Sebastian, Spain. Guest Editors gratefully acknowledge the diligent effort of reviewers for their valuable comments and suggestions that made a significant difference in the development of manuscripts. We would like to express our gratitude to David Audretsch, Donald Kuratko, James Bloodgood and James Hayton. Special thanks go to Domingo Ribeiro-Soriano (main Editor) and David Urbano (regional Editor) of International Entrepreneurship and Management Journal for their invaluable support throughout all the special issue process. Finally, Maribel Guerrero and Iñaki Peña acknowledge the funding received from Global Entrepreneurship Research Association (GERA), Basque Ministry of Education, Basque Government and SPRI (Saiotek 2012-2013). 


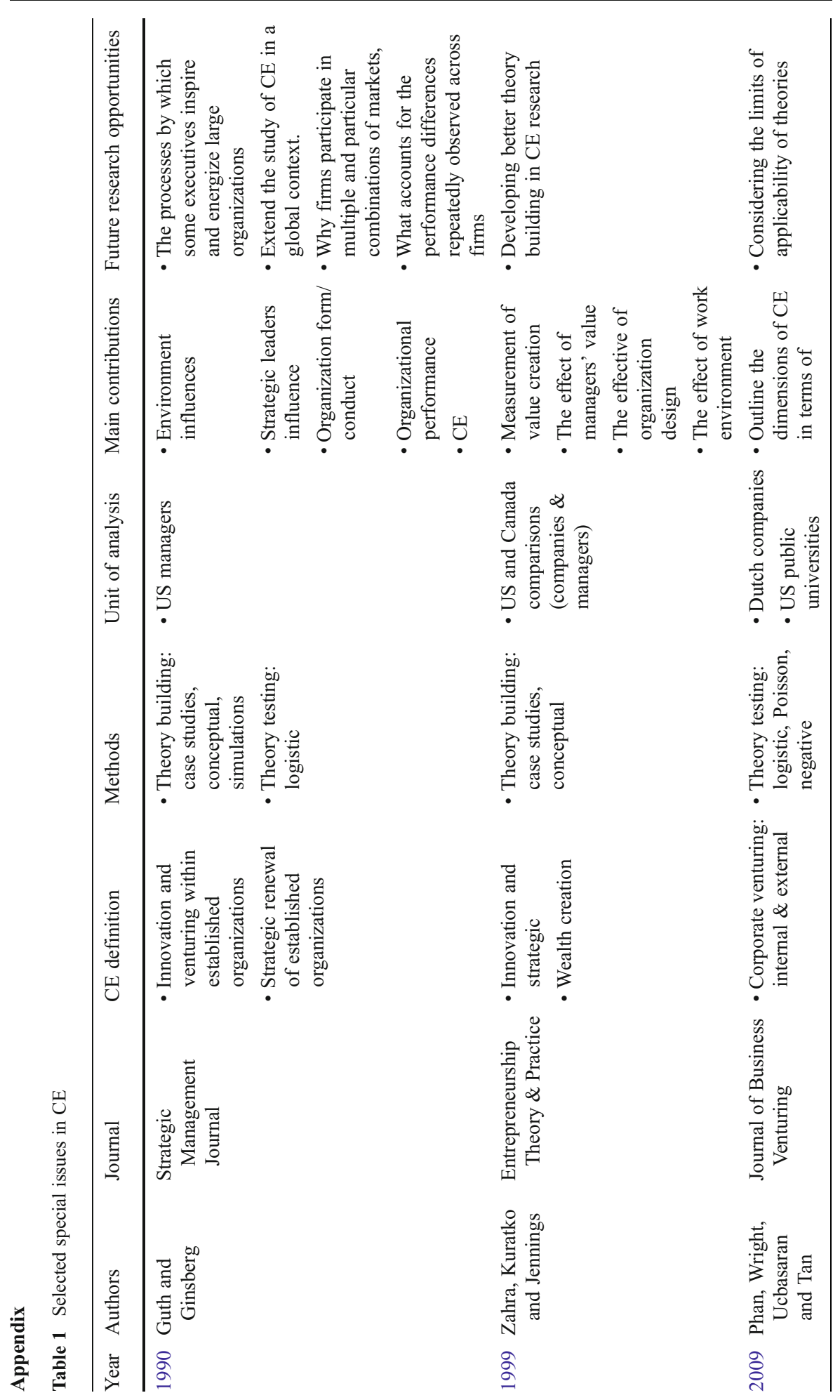




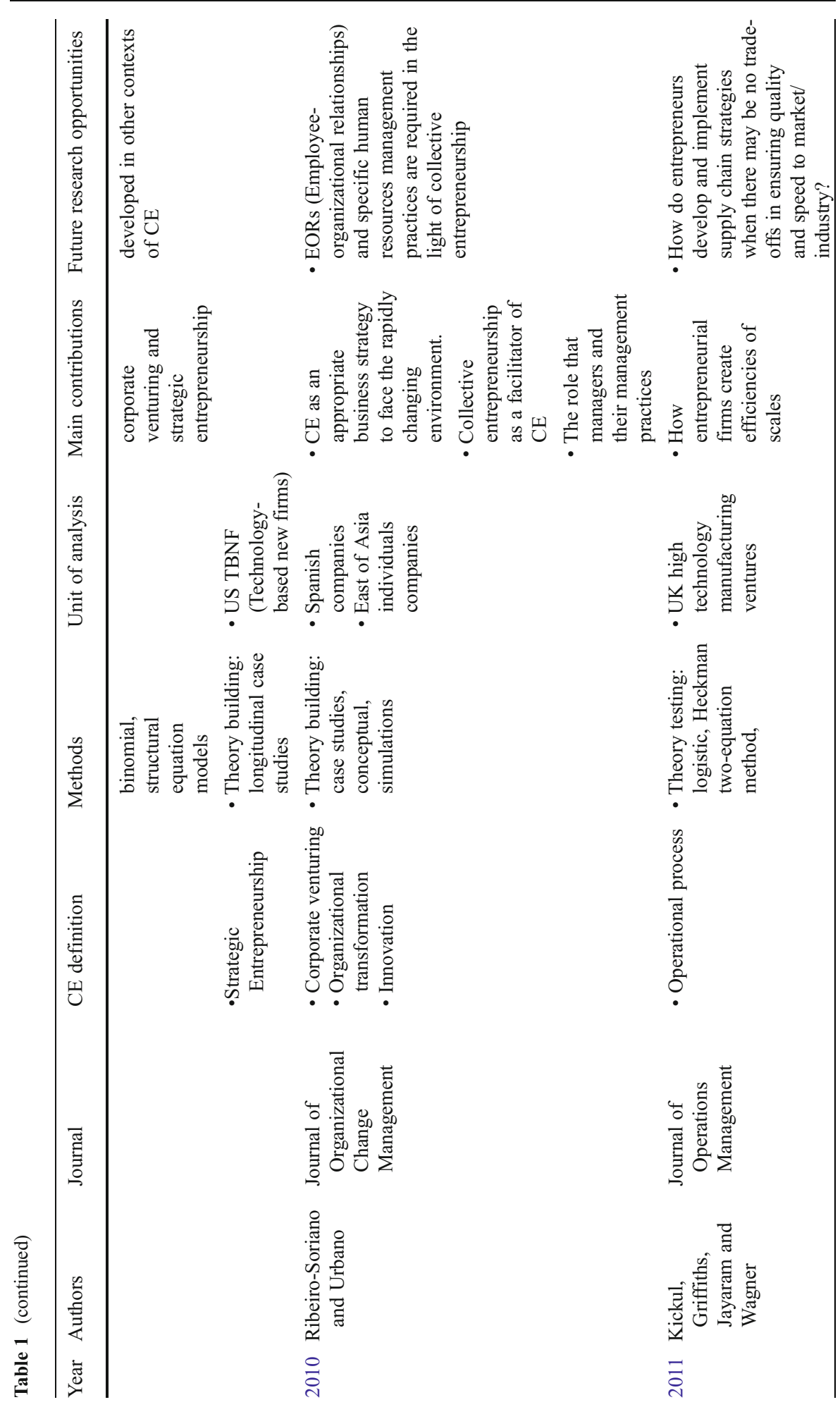




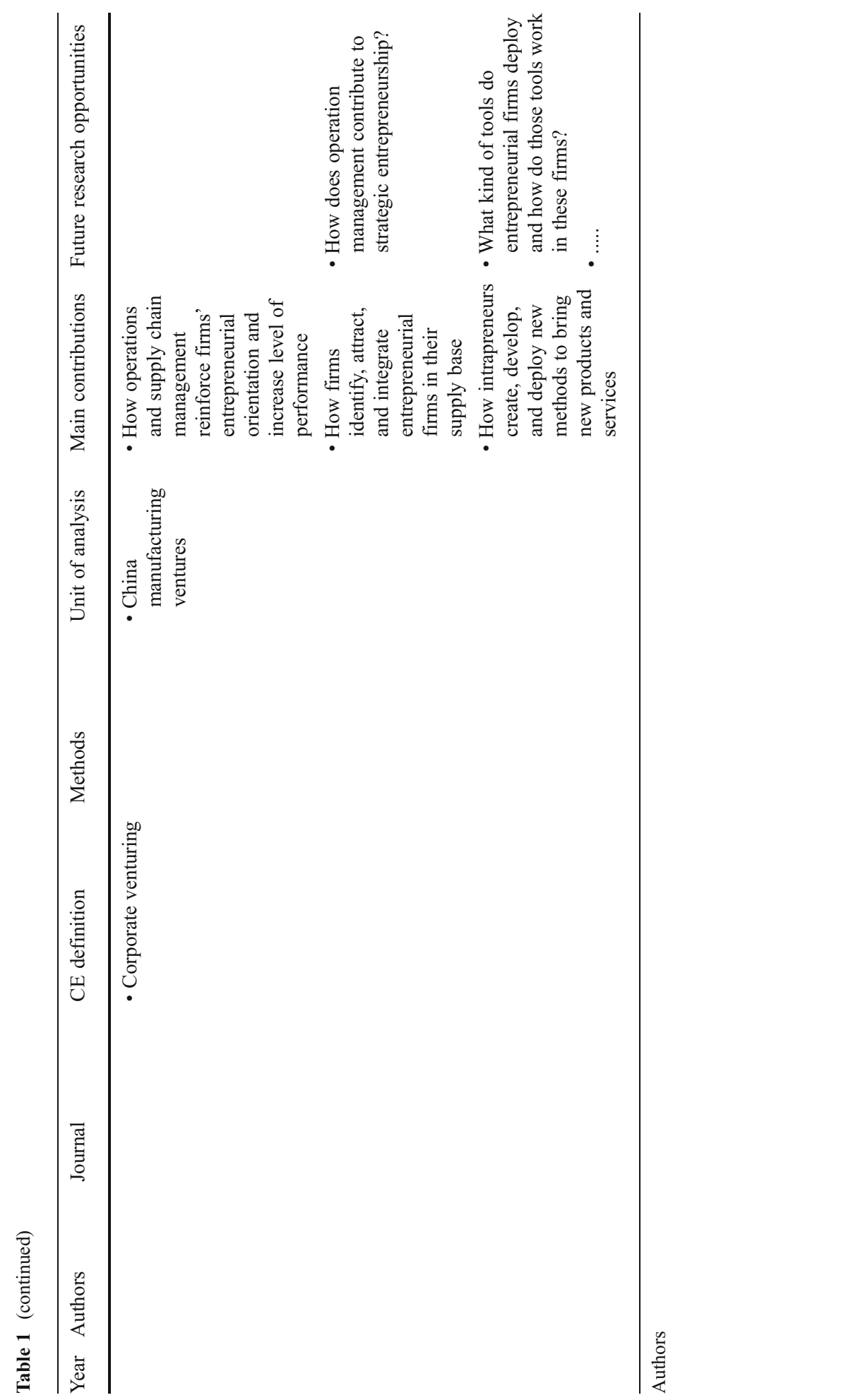




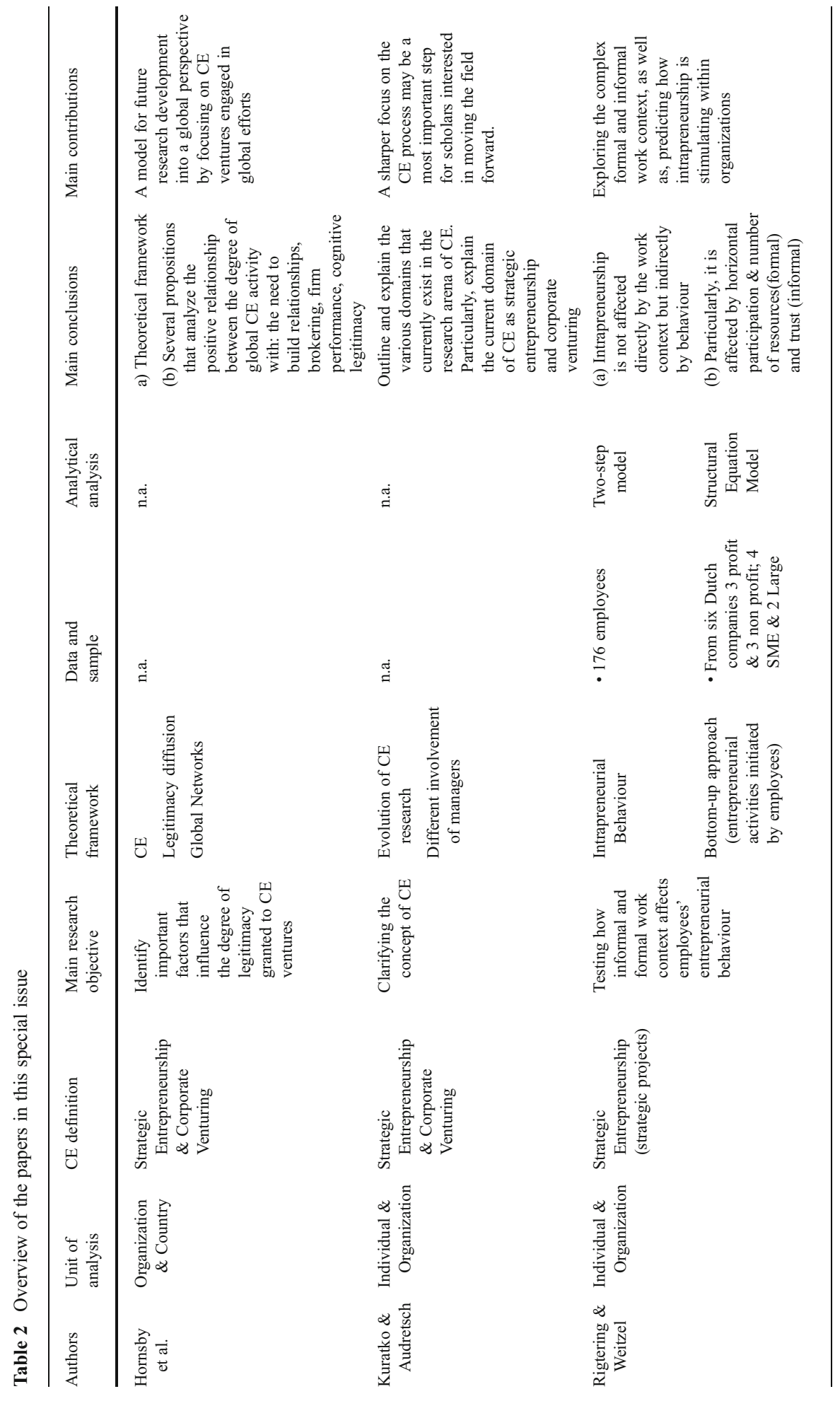




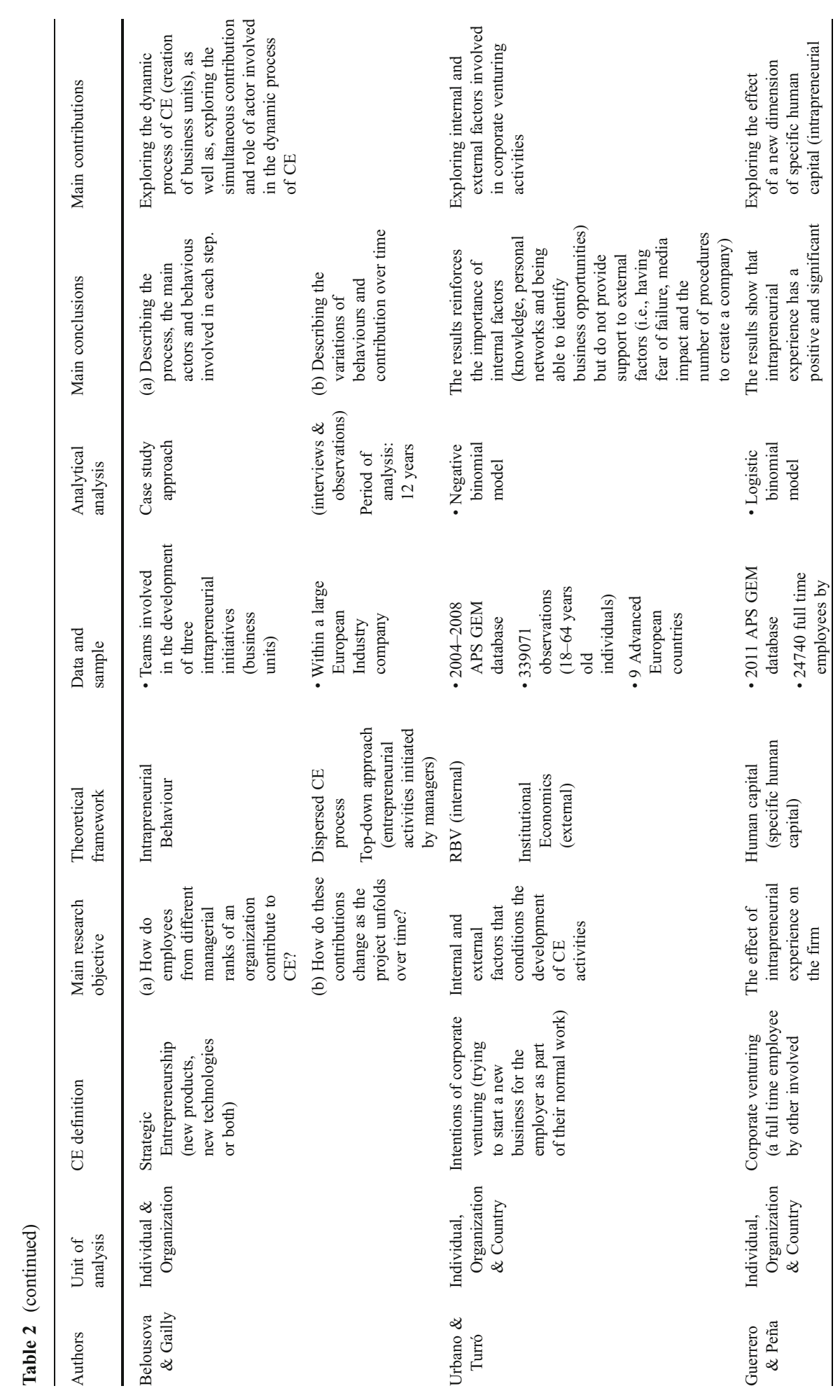




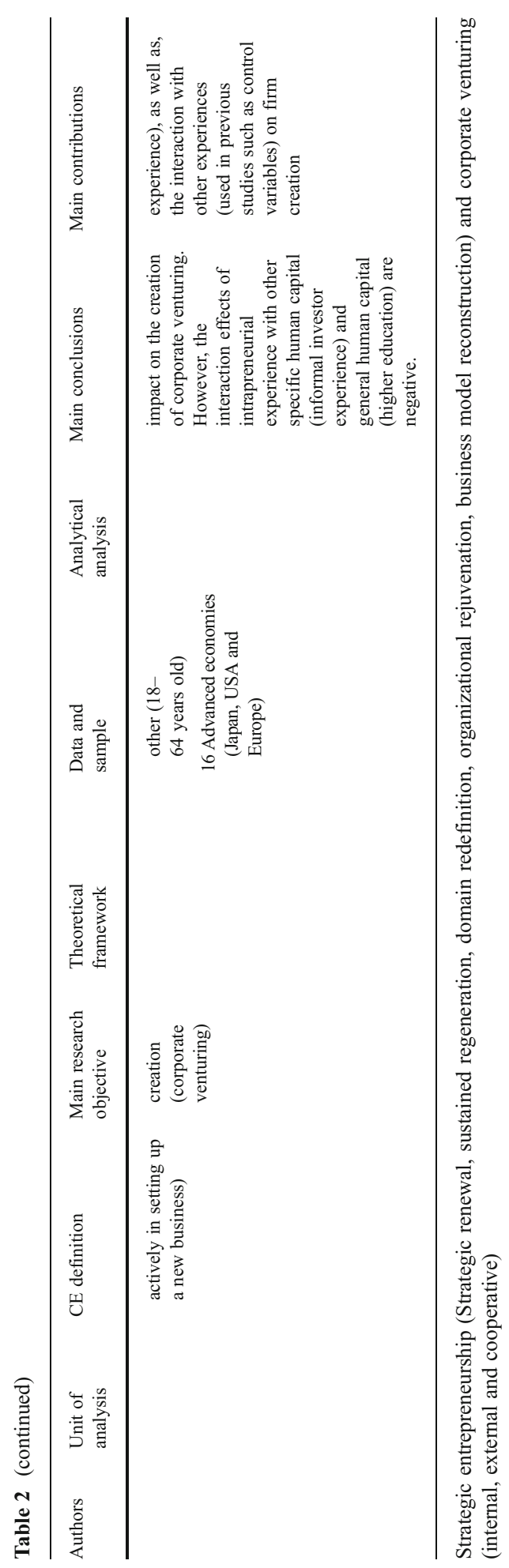




\section{References}

Alpkan, L., Bulut, C., Gunday, G., Ulusoy, G., \& Kilic, K. (2010). Organizational support for intrapreneurship and its interaction with human capital to enhance innovative performance. Management Decision, 48(5), 732-755.

Antoncic, B., \& Hisrich, R. (2001). Intrapreneurship: construct refinement and cross-cultural validation. Journal of Business Venturing, 16, 495-527.

Dess, G., Ireland, R., Zahra, S., Floyd, S., Janney, J., \& Lane, P. (2003). Emerging issues in corporate entrepreneurship. Journal of Management, 29(3), 351-378.

Gómez-Haro, S., Aragón-Correa, J. A., \& Cordón-Pozo, E. (2011). Differentiating the effects of the institutional environment on corporate entrepreneurship. Management Decision, 49(9-10), 1677-1693.

Guth, W., \& Ginsberg, A. (1990). Guest editors' introduction: corporate entrepreneurship. Strategic Management Journal, 11, 5-15.

Kickul, J., Griffiths, M., Jayaram, J., \& Wagner, S. (2011). Special Issue Operations management, entrepreneurship, and value creation: Emerging opportunities in a cross-disciplinary context. Journal of Operations Management, 29(1), 1-162.

McMullen, J. S., \& Shepherd, D. A. (2006). Entrepreneurial action and the role of uncertainty in the theory of entrepreneur. Academy Management Review, 31(1), 132-152.

Mousa, F. T., \& Wales, W. (2012). Founder effectiveness in leveraging entrepreneurial orientation. Management Decision, 50(1-2), 305-324.

Phan, P., Wright, M., Ucbasaran, D., \& Tan, W. (2009). Corporate entrepreneurship: current research and future directions. Journal of Business Venturing, 24, 197-205.

Renko, M., Shrader, R. C., \& Simon, M. (2012). Perception of entrepreneurial opportunity: a general framework. Management Decision, 50(7), 1233-1251.

Ribeiro-Soriano, D., \& Urbano, D. (2010). Employee-organization relationship in collective entrepreneurship: an overview. Journal of Organizational Change Management, 23(4), 349-359.

Yang, T. T., \& Li, C. R. (2011). Competence exploration and exploitation in new product development: the moderating effects of environmental dynamism and competitiveness. Management Decision, 49(9), 1444-1470.

Zahra, S. A., \& Covin, J. G. (1995). Contextual influences on the corporate entrepreneurship performance relationship: a longitudinal analysis. Journal of Business Venturing, 10(1), 43-58.

Zahra, S., Kuratko, D., \& Jennings, D. (1999). Guest editorial. Corporate entrepreneurship and wealth creation: Contemporary and emerging perspectives. Entrepreneurship Theory and Practice, 24. 